\title{
Functional analysis of grimp, a novel gene required for mesodermal cell proliferation at an initial stage of regenera- tion in Enchytraeus japonensis (Enchytraeidae, Oligochaete)
}

\author{
MAKOTO TAKEO $*, 1$, CHIKAKO YOSHIDA-NORO ${ }^{2}$ and SHIN TOCHINAI ${ }^{1}$ \\ ${ }^{1}$ Department of Natural History Sciences, Faculty of Science, Hokkaido University and \\ ${ }^{2}$ Advanced Research Institute for Science and Humanities, Department of Applied Molecular Chemistry, \\ College of Industrial Technology, Nihon University, Japan
}

\begin{abstract}
Enchytraeus japonensis is a small oligochaete species, which has a remarkable regeneration capacity. It has been proposed as a new model animal for the study of regeneration, and some histological studies of this species have been carried out. On the other hand, the molecular biological mechanism of regeneration is almost unknown in this species. To clarify the molecular biological mechanism operating at an initial stage of regeneration in $E$. japonensis, we isolated by the cDNA subtraction method five genes whose expression levels changed in the regeneration process occurring between growing and early regenerating worms. One of the isolated genes (a novel gene named grimp) was expressed transiently from 3 to $12 \mathrm{~h}$ post amputation only in neoblasts and a population of mesodermal cells (the non-neoblast grimpexpressing cells) incorporating BrdU simultaneously showed mitotic activity. We succeeded in inhibiting grimp expression by RNA interference (RNAi), thus applying this technique for the first time in Oligochaeta. In knock-down worms, the number of BrdU-positive neoblasts and the nonneoblast grimp-expressing cells in the coelom drastically decreased. Moreover, the elongation and the segmentation of blastemas were inhibited, while no statistically significant inhibitory effect was observed in epidermal and intestinal cells. These results suggest that grimp is required for initial proliferation of neoblasts and some mesodermal cells for regeneration.
\end{abstract}

KEY WORDS: RNAi, mesodermal cell proliferation, regeneration, Oligochaeta Annelida

\section{Introduction}

Although the regeneration phenomenon is widely distributed in the animal kingdom, the degree and manner of regeneration greatly vary depending on the species. For example, in amphibian limb regeneration, the lost part is regenerated through the formation of a blastema formed by aggregation of undifferentiated cells in the amputated stump (epimorphosis). In contrast, in planarians or hydras, large-scale regeneration of an entire body and the reorganization of remaining tissues are observed (morphallaxis). Moreover, the type of cells contributing to regeneration varies among animals; multipotent stem cells in the regeneration of hydras or planarians, and dedifferentiated cells in amphibian limb or lens regeneration (Sanchez and Tsonis, 2006; Gardiner et al., 2002; Baguna et al., 1989; Bode, 1996).

An annelid oligochaete, Enchytraeus japonensis, has been proposed as a new model animal for the study of regeneration because of its remarkable regeneration capacity and ease of breeding. This worm regenerates by the combination of epimorphosis and morphallaxis (Takeo et al., 2008; Myohara et al., 1999). Fragments either obtained by autotomy or amputation regenerate a tail from the posterior plane in 2-3 days, a head from the anterior plane in $4-5$ days, and the whole body pattern is reorganized in 7 days. The worms grow to the original size in about 2 weeks. It has been suggested that both multipotent stem cells and dedifferentiated cells are involved in whole body regeneration of the worm (Yoshida-Noro et al., 2000). The multipotent meso-

Abbreviations used in this paper: dsRNA, double stranded RNA; ISH, in situ hybridization; ORF, open reading frame; RNAi, RNA interference; WISH, whole-mount in situ hybridization.

\footnotetext{
*Address correspondence to: Dr. Makoto Takeo. Department of Natural History Sciences, Faculty of Science, Hokkaido University, N10W8, Kita-ku, Sapporo 060-0810, Japan. Fax: +81-11-706-4464. e-mail: tko@bio.sci.hokudai.ac.jp
} 
dermal stem cells, the neoblasts, participate in blastema formation (Myohara 2004; Myohara et al., 1999).

Recently, molecular biological techniques such as cDNA subtractive hybridization and RNA interference (RNAi) have been applied to regeneration research in many species. Especially, RNA interference is a very useful technique to know directly the gene function. Thus, some genes needed for regeneration have been identified in hydras and planarians by utilizing this technique (Mannini et al., 2008; Miljkovic-Licina et al., 2007; SanchezAlvarado, 2006; Agata, 2003; Lohmann et al., 1999). Although molecular biological research on regeneration has been conducted in oligochaetes (Niva et al., 2008; Takeo et al., 2008; Myohara et al., 2006; Tadokoro et al., 2006; Martinez et al., 2005; Bely and Wray, 2001; Dupin et al., 1991), gene knock-downs have not yet been succeeded. So far, only four studies utilizing RNAi in other orders of annelids (leech, Hirudinea) have been reported (Baker et al., 2008; Shefi et al., 2006; Biswas et al., 2002; Baker and Macagno, 2000).

In this paper, in order to clarify the molecular mechanisms operating in the early stages of regeneration, we have isolated genes that show changing levels of expression during the regeneration process of $E$. japonensis. One of them, named grimp (gene required for initial mesodermal cell proliferation), is expressed only at the initial stages of regeneration. This molecule has 3 repeat sequences in the $\mathrm{N}$-terminal half and shows no obvious homology to any known genes. We performed a functional knock-down approach to grimp by utilizing RNAi, which was established for the first time in oligochaetes. From our results, it was evident that grimp is necessary for the initiation of mesodermal cell proliferation including neoblasts at a very early stage of regeneration in $E$. japonensis.

\section{Results}

\section{Isolation of genes showing different expression levels} between regenerating and growing worms

By cDNA subtraction made between growing and early regenerating worms, five genes with differential expression levels were obtained. RT-PCR showed that three of them (EjPsmd, EjTuba and grimp) were up-regulated while two others (horu and mino) were down-regulated in an early stage of regeneration than in the intact growing worms (Fig. 1). Although the complete sequences of EjTuba (Enchytraeus japonensis alpha tubulin-like gene), horu (derived from the Japanese word "horumon", which means "intestine") and mino (which means "stomach" in Japanese) have yet to be obtained, EjPsmd (Enchytraeus japonensis Psmd-like gene) and EjTuba showed high homology in NCBI Blastx search to the $26 \mathrm{~S}$ proteasome non-ATPase regulatory subunit gene and the alpha tubulin gene, respectively (Table 1). We analyzed the expression patterns of these five genes by whole mount and section in situ hybridization (WISH and ISH). EjTuba, horu and mino were shown to be expressed in different intestinal parts (Takeo et al., 2008), while no signals of EjPsmd was detected so far examined (data not shown). The strong expression of grimp was observed in the wound site as described later. Since grimp expression seemed to be associated with regeneration, it was further analyzed.

By making 5' and 3' RACE, a 1093 bp-long cDNA fragment

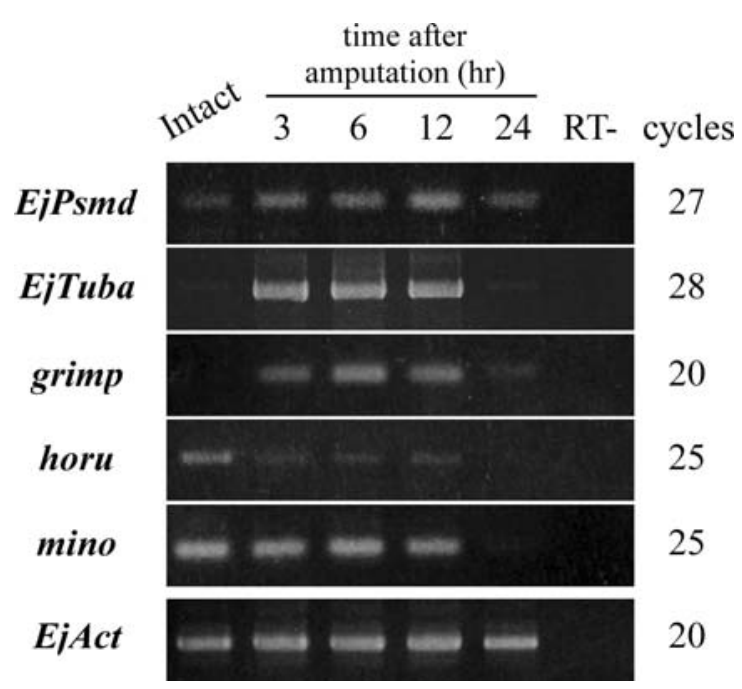

Fig. 1. Gene expression levels in intact and regenerating worms (3, 6, 12 and 24 h post amputation) shown by RT-PCR. The expression levels of EjPsmd, EjTuba and grimp were transiently up-regulated at an early stage, and those of mino and horu decreased as regeneration proceeded. The actin gene (EjAct) was used as an internal control. 'RT'and 'cycles' indicate a control reaction without reverse transcriptase and PCR cycle numbers, respectively.

of grimp containing a putative open reading frame (ORF) and a poly $(A)$ sequence was obtained (Fig. 2A). By Northern blot analysis of the total RNA isolated from $6 \mathrm{hr}$-regenerated worms; a single band about $1.2 \mathrm{kbp}$ long was observed (Fig. 2B). These results indicate that the entire sequence of grimp was successfully isolated. Database searches for nucleotide and deduced amino acid sequence of grimp did not identify any known homologous gene. From the result of ORF analysis in NCBI ORF finder, it was predicted that the region from the 175th to 717 th bp has high probability of containing an ORF (grimp mid region in Fig. $2 \mathrm{~A}$ ). Although no conserved large domains were found in domain analysis for deduced amino acid sequence, it was suspected that the possible polypeptide product of this gene seems neither a transmembrane nor a secretory protein deduced from secondary structure prediction (SOSUI, http:// bp.nuap.nagoya-u.ac.jp/sosui/). On the other hand, from the result of motif search (GENETYX, GENETYX CORPORATION;

\section{TABLE 1}

\section{CLONES ISOLATED BY CDNA SUBTRACTIVE HYBRIDIZATION BETWEEN INTACT AND REGENERATING WORMS}

\begin{tabular}{|c|c|c|c|c|c|}
\hline \multicolumn{2}{|c|}{ obtained genes } & \multicolumn{4}{|c|}{ most similar sequence found in NCBI Blastx search } \\
\hline name & length(bp) & definition & accession \# & bit score & E-value \\
\hline EjPsmd & 2070 & $\begin{array}{l}\text { similar to LOC561267 protein isoform } 1 \\
\text { [Danio rerio] }\end{array}$ & XP_686470 & 469 & $3 e-130$ \\
\hline EjTuba & 1259 & alpha-1 tubulin [Hirudo medicinalis] & AAB07727 & 833 & 0.0 \\
\hline grimp & 1102 & none & & & \\
\hline horu & 778 & $\begin{array}{l}\text { hypothetical protein [Monodelphis } \\
\text { domestica] }\end{array}$ & XP_001375856 & 36.2 & 3.8 \\
\hline mino & 1026 & $\begin{array}{l}\text { hypothetical protein NCU06948 } \\
\text { [Neurospora crassa OR74A] }\end{array}$ & XP_958218 & 72.8 & $4 e-11$ \\
\hline
\end{tabular}

In the five clones of which expression level was different between growing and regenerating worms, only EjPsmd and EjTuba showed high homology to known genes in NCBI Blastx search. 
PPSearch, EMBL-EBI, http://www.ebi.ac.uk/ppsearch/), it was revealed that the deduced polypeptide contains three integrinbinding sequences RGDS (red bars in Fig. 2A and C), five protein kinase $\mathrm{C}(\mathrm{PKC})$ phosphorylation sites (black bars in Fig. 2A and C), one cAMP- and cGMP-dependent protein kinase phosphorylation site (blue bar in Fig. 2A), two N-myristoylation sites (green bars in Fig. 2A) and one casein kinase II phosphorylation site (yellow bar in Fig. 2A). The polypeptide sequence contains 11 chymotrypsin cleavage sites (slashes in Fig. 2A and C) and one possible signal peptidase cleavage site (arrowhead in Fig. 2A). More interestingly, the deduced amino acid sequence revealed that there is a triplicate repeat of a very similar sequence containing RGDS sequences and protein kinase $C$ phosphorylation sites (shaded box in Fig. 2A, and Fig. 2C). Further analyses thus far failed to obtain any helpful information to presume the function of grimp.

In the present study, the predicted ORF was amplified in RT$\mathrm{PCR}$, and the entire sequence of grimp excepting the poly $(\mathrm{A})$ sequence was used to synthesize a probe for Northern blot analysis and ISH. For RNA interference (RNAi) experiment, double-stranded RNAs (dsRNAs) were synthesized using three different regions as follows; the mid region that was expected to contain an ORF (grimp mid region in Fig. 2A), the 5 ' and 3 ' regions of a mid region (grimp 5' and 3' region in Fig. 2A).

\section{Spatial and temporal expression patterns of grimp during early stages of regeneration}

In regenerating $E$. japonensis, wound closure occurs by $3 \mathrm{~h}$ post fragmentation (hpf), and mesodermal cell proliferation is observed in the wound site from 6 hpf. The mesodermal and epidermal cells there actively proliferate at $12-24 \mathrm{hpf}$ resulting in blastema formation. RT-PCR analysis revealed that grimp, which was expressed strongly from $3 \mathrm{hpa}$, peaked from 6 to $12 \mathrm{hpa}$, and then only very weak expression was observed at $24 \mathrm{hpa}$ when the formation of blastema began (Fig. 1).

The spatiotemporal analysis by WISH (Fig. 3 A-F) showed that grimp was expressed in cells found not only around the wound site (arrowheads in Fig. $3 \mathrm{~A}$

Fig. 2. Sequence and Northern Blot analysis. (A) Nucleotide and deduced amino acid sequences of grimp. Deduced amino sequence contains cell attachment integrinbinding sequences (RGDS, red bars), protein kinase $C$ phosphorylation sites (black bars), cAMP- and cGMP-dependent protein kinase phosphorylation site (blue bar), Nmyristoylation sites (green bars) and casein kinase I/ phosphorylation site (yellow bar), chymotrypsin cleavage site (slashes), possible signal peptidase cleavage site (arrowhead), and a triplicate repeat of a very similar sequence (shaded box). In RNA interference examination, dsRNA were synthesized using ORF, and its $5^{\prime}$ and $3^{\prime}$ regions, respectively. (B) Northern blot analysis. A single band of about $1.2 \mathrm{kbp}$ long was observed. Numbers to the left show the position of the RNA base marker. (C) Amino acid sequence alignment among thee repeated sequences. Red and black boxes indicate RGDS sequences, protein kinase C phosphorylation and chymotrypsin cleavage sites, respectively. and $B$ ) but also over the entire fragment from 3 to 6 hpa (Fig. 3 A, $\mathrm{B}$ and $\mathrm{E})$. The expression of grimp weakened throughout the body by 12 hpa (arrowheads in Fig. 3C). At 24 hpa, the expression of grimp was no longer detectable (Fig. 3D). Detailed observation on sagittally sectioned ISH (Fig. 3 G-I') showed that grimp was expressed only in flat cells (the non-neoblast grimp-expressing cells, arrowheads in Fig. 3G, Fig.3I and I') and neoblasts (Fig. $3 \mathrm{H}$ and $\mathrm{H}^{\prime}$ ), both of which were found in the coelom between the bodywall musculature and the digestive tract. On the other hand, grimp expression was never observed in the epidermis, the muscle or the digestive tract (Fig. 3G). Both types of grimp-expressing cells had a large nucleo-cytoplasmic ratio and a large nucleolus (Fig. $3 \mathrm{H}-\mathrm{I}$ '). In addition, neoblasts were several folds larger than the other mesodermal cells, and they were always localized in the particular position close against to the septum, the body wall and the ventral nerve cord. On the other hand, the non-neoblast grimp-expressing cells were scattered in the coelom, and they assumed a flat shape because they were always tightly apposed to the body wall.

\section{Simultaneous grimp ISH and BrdU immunohistochemistry \\ To investigate the association between grimp expression and cell proliferation, simultaneous ISH for grimpand BrdU (5'-bromo-}

A

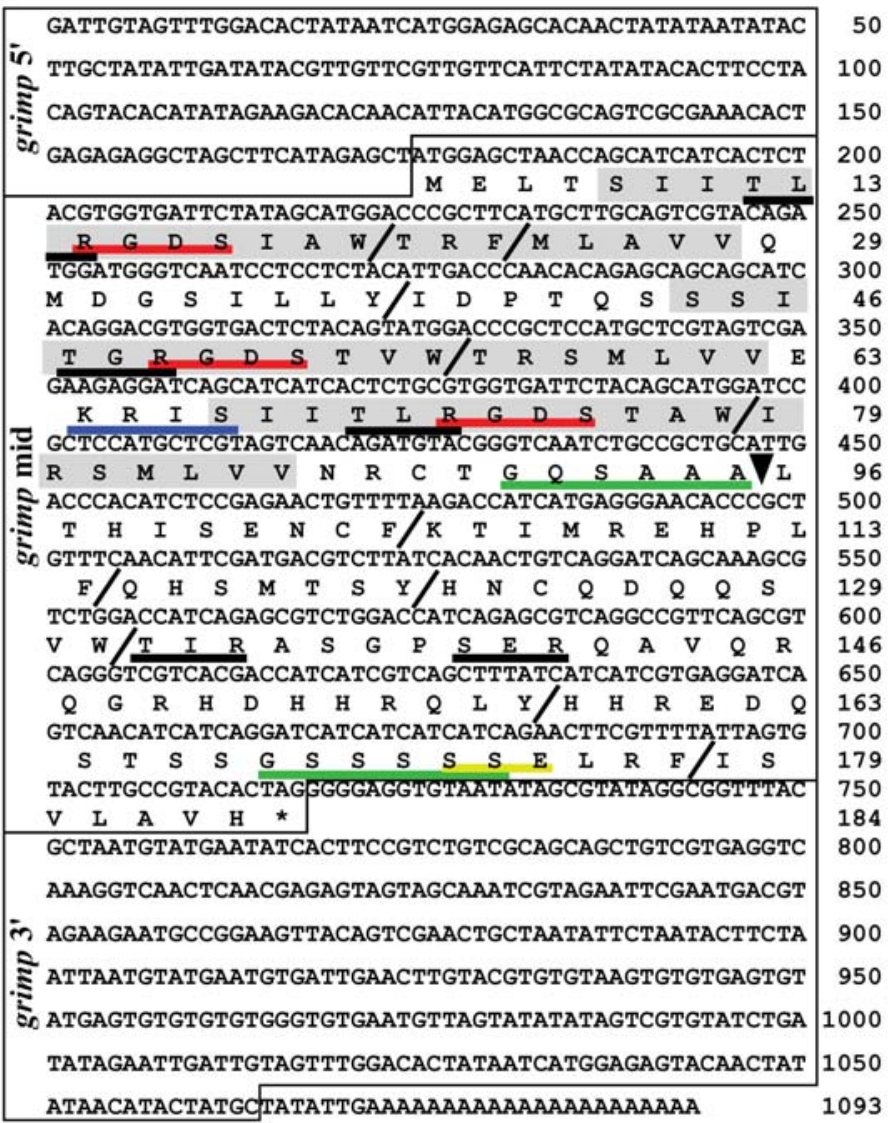

C 100 150 200 29 300 46 350 400 79 450 96 50 650 163 700 800 850 900 950 000 1093

B

$1.5-$

(kb) 

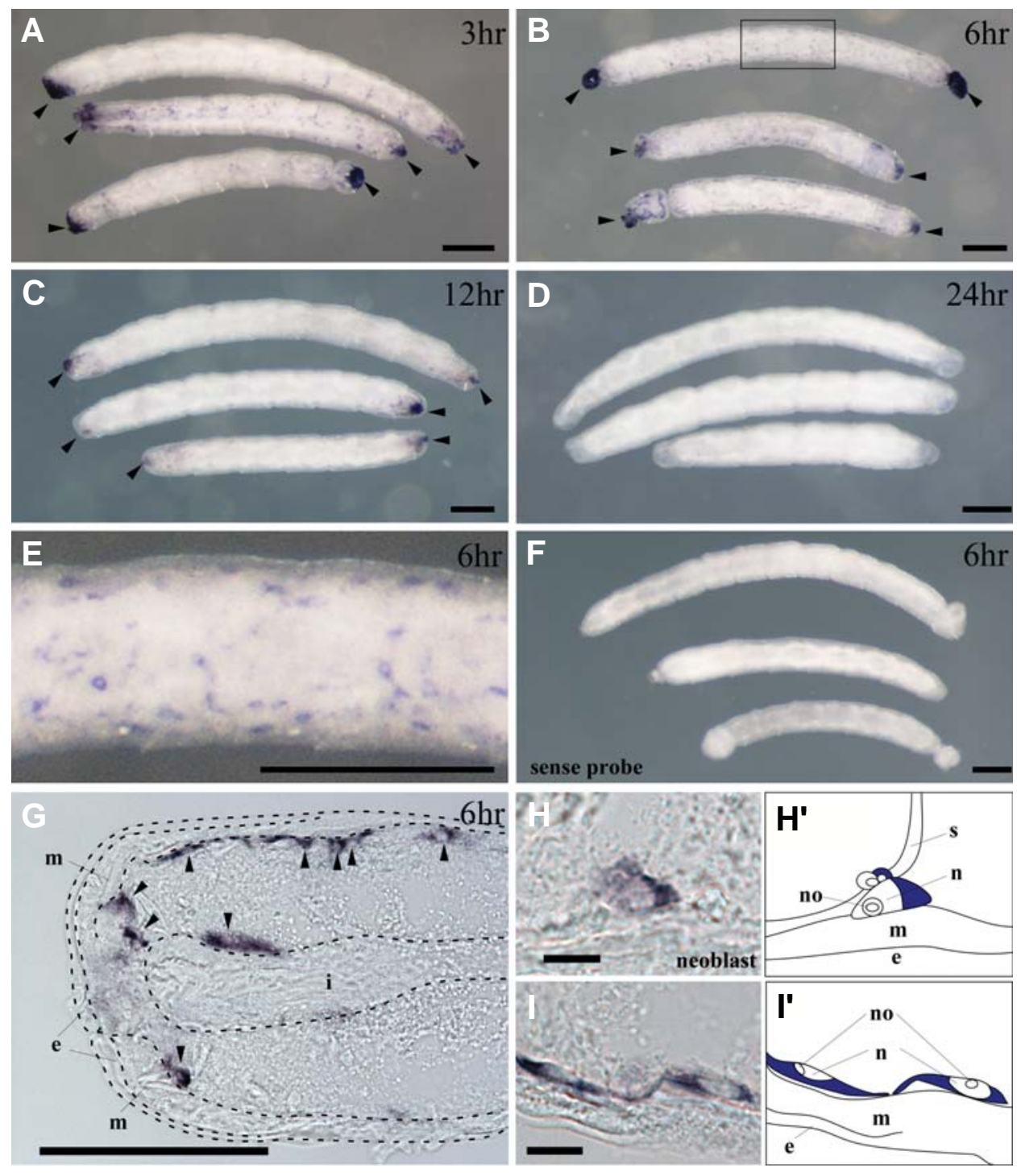

Fig. 3. Spatiotemporal changes of grimp expression in regenerating worms. (A-F) Whole mount in situ hybridization. From 3 to 6 hpa, strong expression of grimp was observed in the wound sites, and numerous grimp-expressing cells were also found over the whole body (A,B,E). Then grimpexpressing cells decreased according to regeneration, and were no longer detectable by 24 hpa (C,D). No signal was observed by using sense probe (F). Panel $E$ is a magnified image of the box in $B$. Arrowheads indicate the grimp expression near the wound site. (G-I) Sagittally sectioned in situ hybridization at 6 hpa. grimp was expressed in mesodermal cells including neoblasts; see arrowheads in $(\mathbf{H}) .\left(\mathbf{H}^{\prime}, \mathbf{I}^{\prime}\right)$ Trace drawings of $(\mathbf{H}, \mathbf{I})$, respectively. e, epidermis; $i$, intestine; $m$, musculature; $n$, nucleus, no; nucleolus; s, septum. In all photographs, the left side is the anterior. Scale bars, $200 \mu \mathrm{m}$ in $(A-G) ; 10 \mu m$ in $(H, I)$.

2'-deoxyuridine) immunohistochemistry was made (Fig. 4). BrdU was incorporated for $3 \mathrm{~h}$ in intact worms prior to fixation. In regenerating worms, successive BrdU incorporation was made (Fig. 4A). The number of grimp and/or BrdU-positive cells per segment was counted since the total number of segments varied in intact ( 32 to 61 segments) and regenerating (8 to 15 segments) worms.

While no grimp-expressing cell was observed in intact worms $(n=4,48.5 \pm 12.4$ segments/worm; Fig. 4B and F), 6.7 $\pm 4.8,6.5$ \pm 5.2 and $0.92 \pm 0.72$ grimp-expressing mesodermal cells/segment were found at 3hpa $(n=6,12.5 \pm 3.0$ segments/fragment;
Fig. $4 C$ and $F)$, 6hpa $(n=10,12.1 \pm 1.3$ segments/fragment; Fig. 4D and F) and $12 \mathrm{hpa}(\mathrm{n}=10,11.7 \pm 2.6$ segments/ fragment; Fig. 4E and F), respectively. In addition, at 3 and $6 \mathrm{hpa}, 0.24 \pm 0.26$ and $0.24 \pm 0.22$ neoblasts also expressed grimp (insets in Fig. 4C and D, Fig. G). The number of grimp-expressing cells peaked at 3 to $6 \mathrm{hpa}$, and grimp-expressing cell was no longer observed after $12 \mathrm{hpa}$.

In contrast, the number of BrdUpositive mesodermal cells increased according to regeneration as follows; $19.8 \pm 11.5$ mesodermal cells and 0.22 \pm 0.13 neoblasts/segment in intact worm, $30.0 \pm 15.9$ mesodermal cells $0.76 \pm 0.88$ neoblasts at 3hpa, $45.1 \pm$ 23.9 mesodermal cells and $0.49 \pm 0.25$ neoblasts at $6 \mathrm{hpa}$, and $38.8 \pm 16.2$ cells and $0.12 \pm 0.09$ neoblasts at $12 \mathrm{hpa}$ (white arrowheads and insets in Fig. 4 B' - E', Fig. F and G). In addition, at $12 \mathrm{hpa}$, active cell proliferation of epithelial cells was also observed in the wound site (white arrows in Fig. 4E'). BrdU-positive cells were also observed in the epidermis and the digestive tract (epidermis, arrows; digestive tract, unmarked BrdU-positive cells in Fig. 4B') in intact worms

Moreover, $16.6 \pm 22.1 \%$ of nonneoblast grimp-expressing cells and $37.5 \pm 49.0 \%$ of grimp-expressing neoblasts at $6 \mathrm{hpa}$, and $8.9 \pm 14.9 \%$ of non-neoblast grimp-expressing cells at $12 \mathrm{hpa}$ were double-positive for both grimp and BrdU (arrowhead with an asterisk and inset in Fig.4 D - D", Fig. $4 \mathrm{~F}$ and $\mathrm{G}$ ).

During regeneration, there is no axial variation in grimp expression/BrdU incorporation related to the distance from the wound except for the wounded segments at the amputation sites.

\section{RNA interference using dsRNA}

To clarify whether grimp expression is linked to the following cell proliferation, an attempt was made to interfere with gene function (RNAi) using dsRNA. Since oligochaetes have a wide coelom space that is separated by net-like septal tissues, any substances injected into a coelom diffuse promptly throughout the body. In fact, in E. japonensis, an injected 25 ntlong rhodamine-conjugated test siRNA in the coelom diffused immediately after injection (Fig. 5A and B). Moreover, siRNA was mostly observed only in nephridia but detected very few coelomic cells at $1 \mathrm{~h}$ after injection (Fig. 5C). It was suspected that the injected siRNA were promptly expelled through nephridia. By repeated injections made once a day for 3 days, it was found that 
siRNA could be incorporated into mesodermal cells, while a major amount of siRNA was still detected in the nephridium (arrowheads in Fig. 5 D and E).

Thus, grimp (grimp mid region in Fig. 2) or control EGFP dsRNA was injected once a day for 3 days, worms were amputated $3 \mathrm{~h}$ after the last injection, and allowed to regenerate for 6 , 12 and $96 \mathrm{hr}$. ISH made at $6 \mathrm{hpa}$ revealed that the aggregation of grimp-expressing cells was observed in EGFP dsRNA-injected worms similar to non-treated regenerating worms (yellow dashed area in Fig. 6A, see also Fig. 4C). On the other hand, in grimp dsRNA-injected worms, it was found that only a few mesodermal cells expressed grimp (arrowheads in Fig. 6B). In RT-PCR analy- sis, it was also confirmed that the expression level of grimp in grimp dsRNA-injected worms was much lower than that in EGFP dsRNA-injected worms (Fig. 6C). These results clearly indicate that the expression of grimp was repressed by grimp dsRNA injection. More interestingly, at $12 \mathrm{hpa}$, the number of BrdUpositive mesodermal cells per segment was drastically decreased in grimp dsRNA-injected worms $(5.6 \pm 4.3$ cells/segment, $n=9$, $7.1 \pm 1.1$ segments/fragment) compared to that in EGFP dsRNAinjected worms $(32.7 \pm 11.2$ cells/segment, $n=9,9.7 \pm 0.9$ segments/fragment; $t=6.94, p<0.001$; $t$-test; Fig. $6 \mathrm{D}, \mathrm{E}$ and $\mathrm{F}$ ). The difference in the number of BrdU-positive neoblasts was statistically significant between EGFP and grimp dsRNA-injected

A

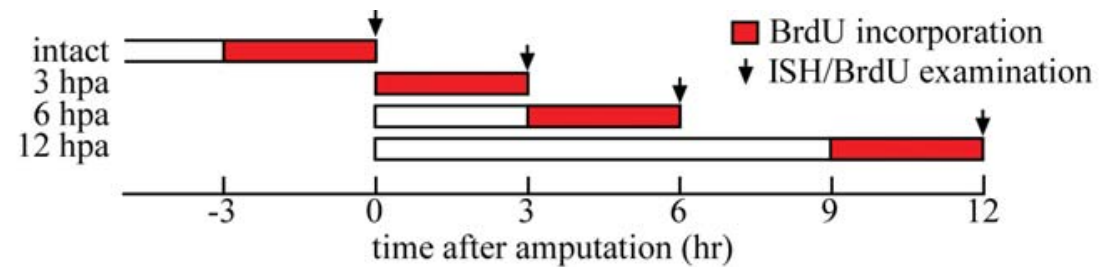

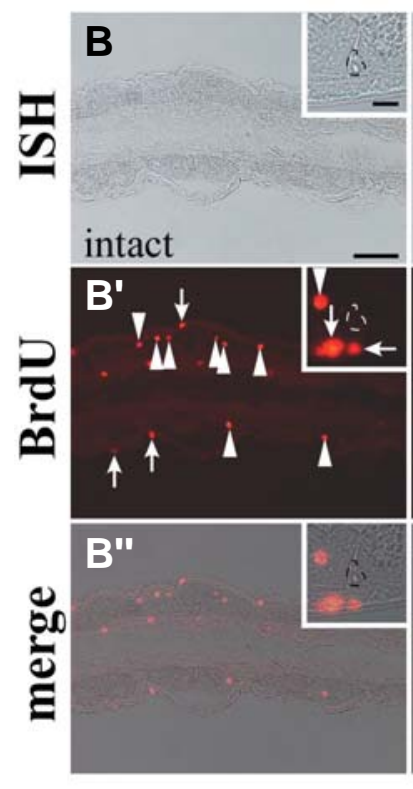

$\mathbf{F}$

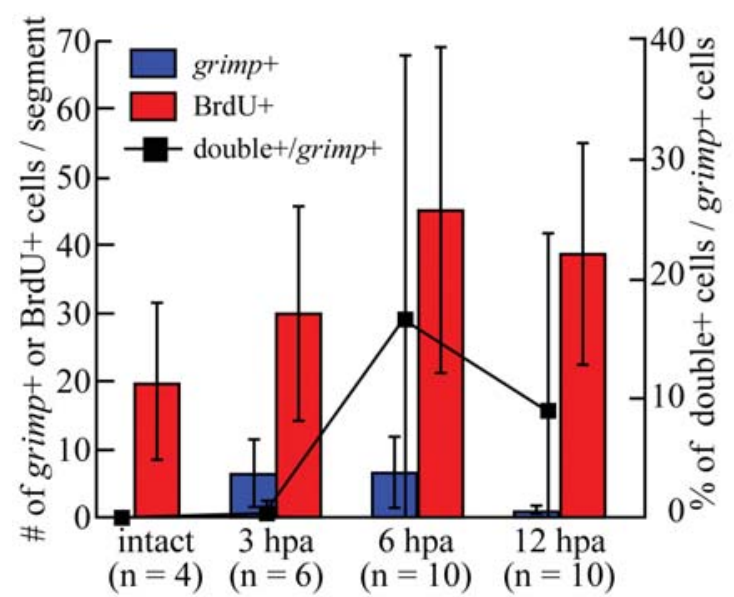

mesodermal cells
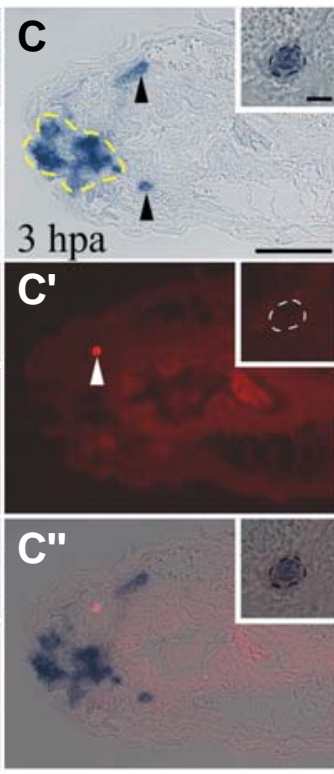

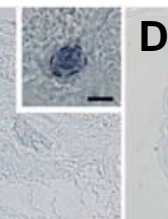

$6 \mathrm{hpa}$

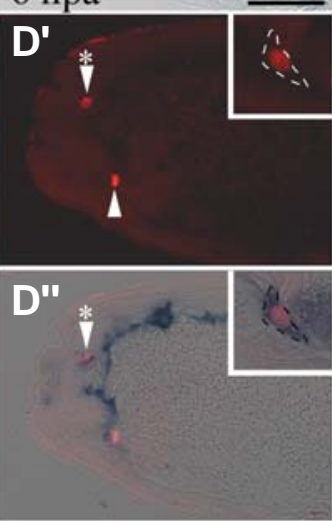

12 hpa
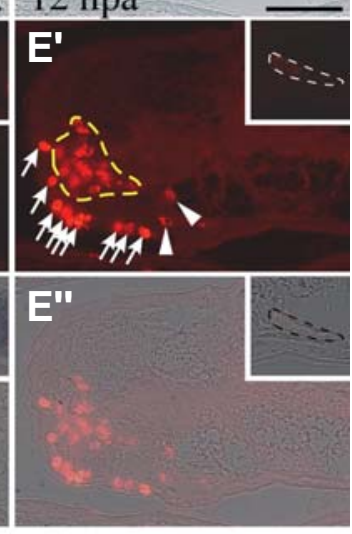

G

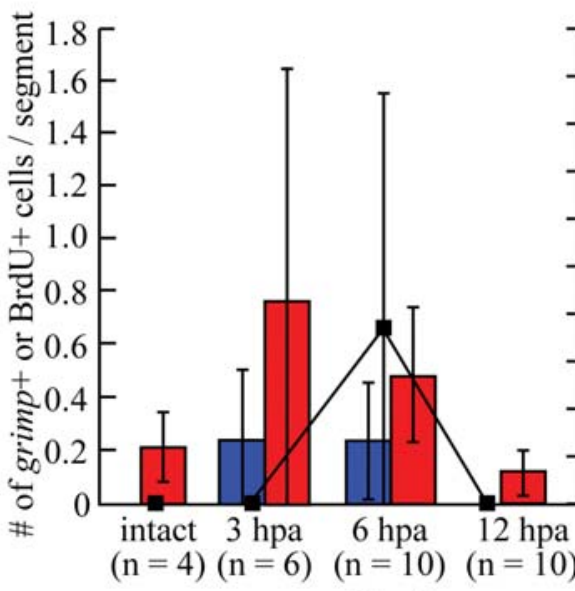

neoblasts
Fig. 4. Simultaneous ISH and BrdU immunohistochemistry. (A) Experimental scheme. BrdU was incorporated for $3 \mathrm{~h}$ prior to fixation. (B-E') ISH (BE), BrdU immunohistochemistry (B'-E') and merged images (B'"-E') on sagittal sections. In intact worms, only BrdU singlepositive cells were found (B, $\left.\mathbf{B}^{\prime}\right)$. At 3 and 6 hpa, many mesodermal cells near the wound site and neoblasts were positive for grimp, see arrowheads and insets in (C,D), and BrdU-positive mesodermal cells were observed in the coelom (C' , D'). A few double-positive cells were also observed at 6 hpa (arrowhead with asterisk and insets in $\left.D-D^{\prime \prime}\right)$. At 12 hpa, grimp expression was no longer observable (E), while the incorporation of BrdU continued in the wound site (E'). White arrowheads and white arrows in (B'-E') indicate BrdU-positive cells in the coelom and the epidermal layer, respectively. Dashed area in insets indicates neoblast. Dashed yellow areas indicate aggregation of grimp-expression or BrdU-positive cells. Scale bars: $50 \mu \mathrm{m}$ and $10 \mu \mathrm{m}$ in insets. $(\mathbf{F}, \mathbf{G})$ Numbers of grimpexpressing (b/ue) and BrdUpositive (red) cells/segment are shown by columns for mesodermal cells (F) and for neoblasts (G), respectively. The rate of double-positive cells to the total number of grimp-expressing mesodermal cells and neoblasts are also plotted in each graph by black squares. Vertical bars show standard deviations. 
worms (EGFP dsRNA-injected worms, $0.6 \pm 0.35$ cell/segment; grimp dsRNA-injected worms, $0.27 \pm 0.21$ cell/ segment; $t=3.04$, $p<0.01$; $t$-test; Fig. $6 \mathrm{~F})$. In contrast, the number of BrdU-positive epidermal cells showed no significant difference between them (EGFP dsRNA-injected worms, $17.0 \pm 8.0$ cells/segment; grimp dsRNA-injected worms, $15.0 \pm 5.5$ cells/segment; $t=0.41, p>0.5$; $t$-test; Fig. 6F). The number of BrdU-positive intestinal cells was $36.0 \pm 8.6$ and $22.8 \pm 11.2$ cells/segment in EGFP and grimp dsRNA-injected worms, respectively (not significantly different, $t$ $=2.921, p>0.1$; $t$-test; Fig. 6F).

In normal regeneration of $E$. japonensis, the segmentation of an anterior blastema is observed and head regeneration is completed by $96 \mathrm{hpa}$ (Myohara, 2004). When regenerating worms was repeatedly injected with dsRNA once a day for 4 days ( $96 \mathrm{hr}$ ), segmentation of the anterior blastemas was observed in $94.1 \%$ of EGFP dsRNA-injected worms ( $n=34$, segments inscribed with Roman numerals in Fig. 6G, Fig. 6l), while the segmentation and the elongation was observed only in $4.2 \%$ of grimp dsRNAinjected worms ( $\mathrm{n}=24$, Fig. $6 \mathrm{H}$ and $\mathrm{I}$ ).

To assess the specificity of the inhibitory effect of grimp RNAi, RNAi experiments were made using grimp 5' and 3' dsRNA (synthesized using grimp 5' and 3' regions in Fig. 2). In both cases,

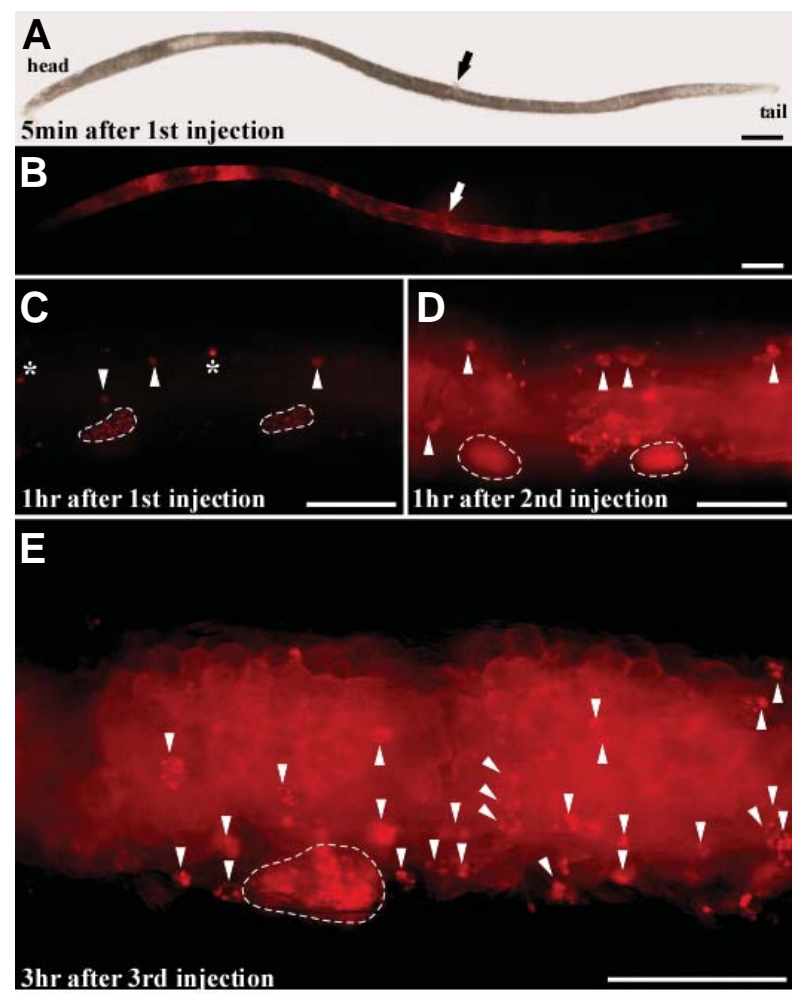

Fig. 5. Repetitive injection of $\mathbf{2 5}$ nt-long rhodamine-conjugated test siRNA in the coelom. Injected 25 nt-long rhodamine-conjugated test siRNA was promptly diffused in the coelom within 5 min after injection (A,B). However, siRNA was mostly observed in nephridia even at $1 \mathrm{~h}$ after injection (C). By repeated injections made once a day for 3 days, siRNAincorporated mesodermal cells were easily found, while a major amount of siRNA was still detected in the nephridium (D,E). Asterisks indicate autofluorescence of setae. Arrow, dashed areas and arrowheads indicate the injection point, nephridia and siRNA-incorporated mesodermal cells, respectively. Scale bars: $500 \mu \mathrm{m}$ in (A,B); $20 \mu \mathrm{m}$ in (C-E). the elongation and the segmentation of anterior blastema were also inhibited (grimp 5' dsRNA, 50.0\% of segmentation, $n=20$; grimp 3' dsRNA, $53.9 \%$ of segmentation, $n=26$ ), although the apparent inhibitory effects decreased in comparison with the experiment using grimp dsRNA (grimp mid region in Fig.2). In intact grimp RNAi-treated animals without amputation, they did not show any defect of proliferation of mesodermal cells in the intact state (data not shown).

\section{Discussion}

\section{Genes isolated by subtraction}

The expression levels of isolated five genes by cDNA subtraction technique changed during the initial stages of regeneration. Among them, EjPsmd and EjTuba showed high homology to the 26S proteasome non-ATPase regulatory subunit and the alpha tubulin genes, respectively by NCBI Blastx search (Table 1). In E. japonensis, a proteasome subunit-like gene has already been reported, and that expression level was shown to be up-regulated during regeneration (Myohara et al., 2006). In many species, the proteasome involves multiple biological processes in the ubiquitin-proteasome pathway, operating during such processes as remodeling of the muscle and progression of the cell cycle by regulating the amount of the cyclindependent kinase inhibitor p27 (Taillandier et al., 2004; Montagnoli et al., 1999; Pagano et al., 1995; Pal et al., 1994). Although the spatial expression pattern of EjPsmd was not clarified in the present study, it could be assumed that this gene is associated with regeneration-related processes such as progression of the cell cycle or wound closure, on the grounds that transient upregulation of EjPsmd expression occurs at an early stage of regeneration (Fig. 1). Generally, it has been known that alpha tubulin is a component of cytoskeletal microtubules that are essential for cell division. In fact, in E. japonensis, it has been indicated that EjTuba is expressed in growth zone and blastema where cells actively proliferate (Takeo et al., 2008). The transient upregulation of EjTuba in an early stage of regeneration might be caused in association with the cell proliferation.

There are several reasons why homologs of the remaining three genes (grimp, horu, mino) could not be identified from existing databases. First, it is highly probable that the many genes expressed in Enchytraeidae may not be common with animals examined so far including even oligochaete species such as Lumbricus and Eisenia. Moreover, it is apparent that part or entire coding regions are missing from horu and mino sequences because the 5 ' sequence has yet to be obtained. In the case of grimp, whose entire sequence has been obtained, the expression is very much limited to the early stage of regeneration, resulting in the possible failure of registration even in the earthworm EST databases (LumbriBASE and EandreiBASE).

\section{Success of RNA interference}

RNA interference is a very useful technique to know the function of given genes, and it has been utilized in regeneration studies of hydras and planarians (Mannini et al., 2008; MiljkovicLicina et al., 2007; Sanchez-Alvarado, 2006; Agata, 2003; Lohmann et al., 1999). However, the same technique has not 
yet been established in any oligochaete species, while four experiments have so far been reported on another order of annelids (leech, Hirudinea) (Baker et al., 2008; Shefi et al., 2006; Biswas et al., 2002; Baker and Macagno., 2000).

In the analysis utilizing RNAi, a variety of animals are soaked in, injected with, or fed with RNA solutions to make their cells incorporate dsRNA or siRNA. Almost all test siRNA injected into the coelom of $E$. japonensis was promptly taken into nephridia in the present study (Fig. 5). Either the use of lipofection reagent or keeping worms at low temperature failed to make mesodermal cells in the coelom incorporate siRNA. However, it was found that siRNA was incorporated into mesodermal cells by simply injecting solutions once a day up to 3 days, while much siRNA was still detected in the nephridia. This might be because the total amount of injected siRNA exceeded the capacity of the nephridia.

By injecting grimp dsRNA once a day for 1 to 2 days, worms regenerated as control EGFP dsRNA-injected worms (data not shown). On the other hand, when the injection of grimp dsRNA was extended to 3 days, grimp expression, BrdU incorporation in coelomic mesodermal cells, and the elongation and the segmentation of the anterior blastema were all inhibited (Fig. $6)$. The same phenotype was also observed in similar experiments using grimp 5' or 3' dsRNA, although the inhibition was less severe than the experiment using grimp dsRNA. It has been indicated that the inhibitory efficiency of dsRNA injection increases with increasing dsRNA length (Yang et al., 2000). The length of grimp, grimp 5' and 3' dsRNA was 543, 174 and $347 \mathrm{bp}$, respectively and this difference in length may be the cause of the inhibitory efficiency among experiments. Because $\mathrm{H}_{2} \mathrm{O}$ - and EGFP dsRNA-treated worms who were injected with technically possible highest concentration of dsRNA $(5 \mu \mathrm{g} / \mu \mathrm{l})$ regenerated as non-treated worms (data not shown), it is highly improbable that there was non-specific effect of RNA injection. These results suggest that the function of the grimp gene was specifically down-regulated by the injection of grimp dsRNA

Apart from the findings described above, the establishment of the RNAi technique in this species will increase the usefulness of $E$. japonensis as a model animal for regeneration studies.

\section{6 hpa: ISH and RT-PCR}

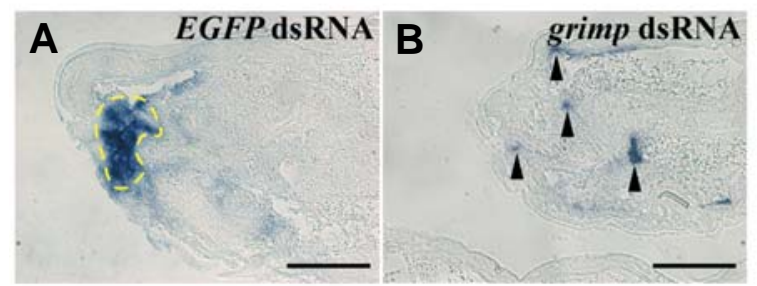

\section{2 hpa: BrdU immunohistochemistry}
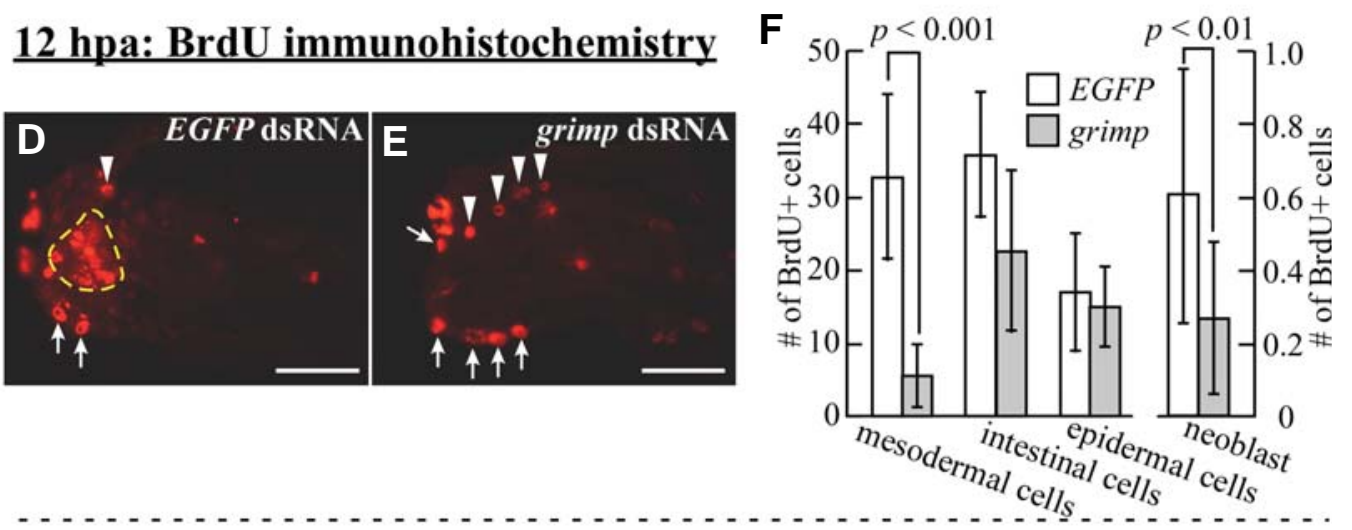

\section{6 hpa: somatoscopy}

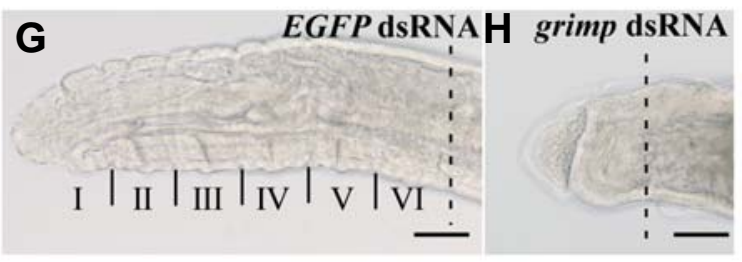

C

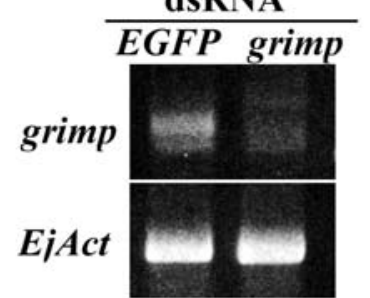

dsRNA 


\section{Expression of grimp promotes mesodermal stem cells to proliferate in initial stage of regeneration}

In zebrafish and axolotls, it has been indicated that the proliferation and migration of mesenchymal cells are inhibited and the blastema is not formed by obstructing the TGF-beta or FGF signaling pathway (Jazwinska et al., 2007; Levesque et al., 2007; Thummel et al., 2006; O'Kane and Ferguson, 1997). In addition, it has also been reported that Smad4 involved in the TGF-beta pathway is necessary for the proliferation of stem cells in planarians (Reddien et al., 2005). In Oligochaeta, including $E$. japonensis, although some molecular biological research has been made, no genes required for the initiation and the progression of regeneration have yet been identified (Myohara et al., 2006; Martinez et al., 2005; Bely and Wray, 2001; Dupin et al., 1991). In the present study, we found one of the key genes required for the initiation of regeneration, grimp is strongly expressed in neoblasts and in a subset of mesodermal cells in the coelom (Figs. 3 and 4). In addition, grimp was expressed only transiently from 3 hpa (when wound closure occurred) to $12 \mathrm{hpa}$ (when active cell proliferation occurred at wound site), while occasional cell proliferations were observed even in intact worms (Figs. 1 and 3). Some grimp-expressing cells also incorporated BrdU at the same time (Fig. 4). In grimp dsRNA-injected worms, both the expression level of grimp and the number of grimp-expressing cells, and also the number of proliferating neoblasts and mesodermal cells scattered in the coelom decreased. Moreover, at $96 \mathrm{hpa}$, the elongation and segmentation of the anterior blastema was also inhibited in these worms (Fig. 6). The influence of RNAi, in contrast, was not significantly affected the proliferation of intestinal cells and epidermal cells in which grimp was not expressed at all (Fig. 6). Non grimp-expressing intestinal proliferation was reduced by about one third, although that reduction was not statistically significant. It could be that the RNAi effect is simply less penetrant in intestinal cells but that grimp is nevertheless important for that proliferation, or that grimp-expressing cells affect intestinal proliferation indirectly.

These results suggest that grimp is not related to cell proliferation in general, but is closely connected to a key process for the initiation of proliferation only in mesodermal cells, including the neoblasts, at initial stages of regeneration. Thus, we named this gene grimp (gene required for initial mesodermal cell proliferation). It seems that mesodermal cells may have two proliferation systems; 1) grimp-independent the physiological proliferation for body maintenance and 2) grimp-dependent emergent proliferation for regeneration triggered by the amputation signal.

The deduced amino acid sequence of grimp has a triplicate repeat of a very similar sequence containing RGDS sequences and protein kinase $C$ (PKC) phosphorylation sites and a chymotrypsin cleavage site. It has been previously indicated that the integrin-binding sequence (RGDS) was also found in fibronectin (Ruoslahti and Pierschbacher, 1986), that RGDmediated cell adhesion was necessary for cell migration in gastrulation and wound closure in axolotls and, quite interestingly, intestinal regeneration in sea cucumbers (Cabrera-Serrano and Garcia-Arraras, 2004; Donaldson et al., 1987). Although it is not certain whether the translated product of grimp is a distinct signal peptide carried outside cells because a distinct signal peptide was not identified, and RGD-mediated cell adhesion might play an important role in initiation of mesodermal cell proliferation in E. japonensis. Connected to this, it should be mentioned that the peptide contains a possible site which is cleaved by the signal peptidase. In addition, it has been known that PKC takes part in cellular responses to various signals such as hormones and growth factors and that its phosphorylating activities are essential for numerous processes, including cell proliferation and differentiation (Moraczewski et al., 2008; Nishizuka, 1992). Although any helpful information for presumption of interaction between grimp and other genes was not obtained in the present study, the presence of many PKC phosphorylation sites may indicate that grimp may be located downstream of growth factors such as TGF-beta and FGF. The function of grimp is no more than a speculation, as depicted above, at this time. It is still unclear whether this gene is actually translated into a polypeptide or not. Attempts to raise antibodies against partial peptide sequence or recombinant protein of grimp are in progress for further analysis. Also, screening of genes affected by grimp dsRNA is under way.

Earthworms have ectodermal, mesodermal and endodermal stem cells (Jamieson, 1981), and neoblasts are thought as mesodermal stem cells in E. japonensis (Tadokoro et al., 2006). Although the size is quite different between the non-neoblast grimp-expressing cells and neoblasts, they have common histological features such as a large nucleo-cytoplasmic ratio, and enhanced proliferation during early stages of regeneration. In addition, it has been reported that a vasa-like gene (Ejvlg2) is expressed in both neoblasts and that smaller cells are similar to neoblasts in morphology (Sugio et al., 2008). From these and the present RNAi experiment, it is highly probable that neoblasts and the non-neoblast grimp-expressing cells have a common property, suggesting that the cells in blastemas were provided from not only neoblast but also the non-neoblast grimp-expressing cells. That means, in turn, that there are two types of mesodermal stem cells over the entire body in E. japonensis.

\section{Materials and Methods}

\section{Animals and regenerating fragments}

An enchytraeid worm Enchytraeus japonensis has been cultured asexually in our laboratory as described previously (Kawamoto et al., 2005). Al fragments were cut artificially using a disposable surgical blade to contain about 10 segments. The fragments from the trunk region having amputated

TABLE 2

GENE-SPECIFIC PRIMERS FOR RT-PCR

\begin{tabular}{ll} 
Gene name & primer sequences \\
\hline EjPsmd & 5' - ACTTGAGAGCTAGCTTACCAC - 3' \\
EjTuba & 5' - ACATGCTGCTCTGTAAGATCA - 3' \\
grimp & 5' - CAATGCCTGCTGGGAGTTGTA - 3' \\
& 5' - ACTCCGACCTCCTCGTAATCT- 3' \\
horu & 5' - ATGGAGCTAACCAGCATCATC - 3' \\
& 5' - CTAATAAAAACGAAGTTCTGA - 3' \\
mino & 5' - TTGCTCTGTTTGCAACCAAGA - 3' \\
& 5' - TGTCACGGTCAGGGTTACGAC - 3' \\
EjAct & 5' - ACGCGGGGTTCAGTATTATCT - 3' \\
& 5' - ACTCAAAGAACTTCCTCAACC - 3' \\
& 5' - AATTGGGATGATATGGAGAAG - 3' \\
\hline
\end{tabular}


stump at both ends were cultured on a $0.8 \%$ agar plate $(60-\mathrm{mm}$ in diameter) at $24^{\circ} \mathrm{C}$, and fixed at $3,6,12$ and 96 hours after amputation (hpa).

\section{Subtractive hybridization}

To isolate differentially expressed genes, we performed cDNA subtractive hybridization between growing worms and regenerating worms 6 or $12 \mathrm{~h}$ after amputation according to a previously described protocol (Takeo et al., 2008). Through cDNA subtractive hybridization and RTPCR analysis, five genes were isolated and expanded by $3^{\prime}$ and $5^{\prime}$ direction RACE. Then, sequences were compared with known and predicted nucleotide sequences using the National Center of Biotechnology Information (NCBI) and the earthworm EST databases (LumbriBASE and EandreiBASE), and also searched for conserved domains on each predicted amino acid sequence using NCBI Conserved Domain Search server. The open reading frame was found by the NCBI ORF Finder. EjPsmd (Gene accession number AB430779) and EjTuba (Gene accession number EU118298) were shown to have high homology to the $26 \mathrm{~S}$ proteasome non-ATPase regulatory subunit and the alpha tubulin gene, respectively. Any homologous genes for the remaining three were not identified (grimp, Gene accession number AB430780). Gene accession numbers of mino and horu are EU118299 and EU118300, respectively.

\section{Semi-quantitative RT-PCR}

Total RNA was extracted from intact worms and regenerating fragments at 3, 6, 12 and $24 \mathrm{~h}$ after amputation using ISOGEN (NIPPON GENE), then cDNA was synthesized using SMARTTM PCR cDNA Synthesis kit (CLONTECH). The E. japonensis actin gene EjAct was amplified as an internal control. The list of gene-specific primers is presented in Table 2.

\section{Northern blot analysis}

By using an entire sequence of grimp other than poly $(A)$ tail, the digoxigenin-labeled RNA probes were synthesized using the DIG RNA labeling kit (SP6/T7, Roche), and were degraded by alkaline hydrolysis to fragments of approximately $500 \mathrm{nt}$ in length. Total RNA (10 $\mu \mathrm{g}$ per lane) was fractioned by $1 \%$ formaldehyde-agarose denaturing gel electrophoresis. Following electrophoresis, the gel was incubated in $50 \mathrm{mM}$ $\mathrm{NaOH}$ for $25 \mathrm{~min}, 200 \mathrm{mM} \mathrm{NaOAc}$ for 20 min twice. Then total RNA was transferred to a Hybond-N+ membrane using upward capillary transfer with 20x SSC. Gel electrophoresis and transfer of total RNA to the membrane were carried out in accordance with standard protocols (Sambrook et al., 2001). The transferred membrane was incubated in $0.05 \mathrm{~N} \mathrm{NaOH}$ for $5 \mathrm{~min}, 2 \times \mathrm{SSC}$ for $30 \mathrm{~min}$, then baked at $80^{\circ} \mathrm{C}$ for $2 \mathrm{hrs}$ to fix total RNA. Following prehybridization that was carried out at $50^{\circ} \mathrm{C}$ for $1 \mathrm{~h}$ in hybridization buffer $(50 \%$ deionized formamide, $5 \mathrm{x}$ SSC, $2 \mathrm{x}$ Denhardt's solution, $1 \%$ SDS), the membrane was incubated in fresh hybridization buffer containing $100 \mathrm{ng} / \mathrm{ml}$ of the probe at $50^{\circ} \mathrm{C}$ for $16 \mathrm{hr}$. The hybridized membrane was washed twice in 2x SSC for 5 min each, washed twice in $0.2 \times \mathrm{SSC} / 0.1 \% \mathrm{SDS}$ at $60^{\circ} \mathrm{C}$ for $30 \mathrm{~min}$ each. Washed membrane was incubated at room temperature for $1 \mathrm{~h}$ in $1 \%$ blocking reagents (Roche) in maleic acid solution $(0.1 \mathrm{M}$ maleic acid, $0.15 \mathrm{M} \mathrm{NaCl}$,

TABLE 3

\section{GENE-SPECIFIC PRIMERS FOR dSRNA SYNTHESIS}

\begin{tabular}{ll} 
dsRNA & primer sequences \\
\hline grimp & 5' - TAATACGACTCACTATAgggcgTAGGAGCTAACCAGCATCA - 3' \\
& 5' - TAATACGACTCACTATAgggcgCTAATAAAAACGAAGTTCT - 3' \\
grimp5' & 5' - TAATACGACTCACTATAgggcgGATTGTAGTTTGGACACT - 3' \\
& 5' - TAATACGACTCACTATAgggcgAGCTCTATGAAGCTAGCC - 3' \\
grimp3' & 5' - TAATACGACTCACTATAgggcgTGTACTTGCCGTACACTA - 3' \\
& 5' - TAATACGACTCACTATAgggcgGCAAGTATATTATACAGT - 3' \\
EGFP & 5' - TAATACGACTCACTATAgggcgATGGTGAGCAAGGGCGAG - 3' \\
& 5' - TAATACGACTCACTATAgggcgTTGAAGTTCACCTTGATG - 3' \\
\hline
\end{tabular}

$0.1 \%$ Triton- $\mathrm{X} 100, \mathrm{pH} 7.5)$, then incubated at room temperature for $1 \mathrm{~h}$ with 1/2000 Anti-Dig/AP antibody (Roche) in 1\% blocking reagents. After incubation, the membrane was washed three times in PBS for 20 min each, and a color reaction was performed with nitroblue tetrazolium/5bromo-4-chloro-3-indolyl phosphate (NBT/BCIP) solution (Sigma).

\section{Whole-mount and section in situ hybridization (WISH and ISH)}

We synthesized a probe in a manner similar to that in Northern blot analysis, and performed whole-mount and section in situ hybridization essentially as described previously (Takeo et al., 2008). The major modifications were that the prehybridization and hybridization were carried out at $50^{\circ} \mathrm{C}$.

\section{Simultaneous ISH and BrdU immunohistochemistry}

The intact and regenerating worms were soaked into $20 \mathrm{mM} \mathrm{BrdU}$ (5'bromo-2'-deoxyuridine, SIGMA) for $3 \mathrm{hrs}$. After soaking, the worms were fixed with $4 \%$ paraformaldehyde at room temperature overnight. Following usual ISH as described above, the specimens were treated with $2 \mathrm{~N}$ $\mathrm{HCl}$ for $30 \mathrm{~min}$, neutralized with $0.1 \mathrm{M}$ sodium borate buffer $(\mathrm{pH} 8.5)$ twice for 15 min each, washed in PBS, incubated with a 10\% Fetal Calf Serum (FCS) blocking solution for $10 \mathrm{~min}$ followed by the rat monoclonal antiBrdU antibody (50 $\mu \mathrm{g} / \mathrm{ml}$ in PBS with $10 \% \mathrm{FCS}$ and $0.1 \% \mathrm{NaN}_{3}$, abcam) for $2 \mathrm{hrs}$. The sections were then visualized with a rhodamine-conjugated goat anti-rat lgG antibody ( $30 \mu \mathrm{g} / \mathrm{ml}$ in PBS, ROCKLAND) for $2 \mathrm{hrs}$, rinsed with PBS, mounted with $50 \%$ glycerol and observed with a fluorescence microscope.

\section{RNA interference experiments}

Double stranded RNAs (dsRNAs) were synthesized according to the protocol for Drosophila (Kennerdell and Carthew, 1998). The template for three different types of grimp and EGFP dsRNA synthesis were amplified using gene-specific primers containing 18 or 19 gene-specific nucleotides and a T7 promoter sequence with an extra "gggcg", as presented in Table 3. Single stranded RNA was synthesized using T7 RNA polymerase (Roche), purified by RNeasy Mini kit@ (Qiagen), annealed at $65^{\circ} \mathrm{C}$ for 15 min, at $37^{\circ} \mathrm{C}$ for $60 \mathrm{~min}$, and then at $4^{\circ} \mathrm{C}$ overnight. The quality and quantity of dsRNA were analyzed by agarose gel electrophoresis. RNA interference (RNAi) was performed by injection of grimp dsRNA or EGFP dsRNA ( $1 \mu \mathrm{g} / \mu \mathrm{l}, 100 \mathrm{nl}$ per worm) as a negative control. Under anesthetization in a saturated L-menthol solution, intact worms were injected with dsRNA into the coelom once a day for three days. Thee hours after the last injection the worms were transected without anesthesia, and allowed to regenerate for 6,12 and $96 \mathrm{~h}$ with additional dsRNA booster injection 24 $\mathrm{h}$ after amputation ( $1 \mu \mathrm{g} / \mu \mathrm{l}, 20 \mathrm{nl}$ per fragment).

\section{Acknowledgements}

The authors would like to thank the members of the Tochinai laboratory. This research was supported by the 21st Century Center of Excellence (COE) Program on the 'Neo-Science of Natural History' (Program Leader: Hisatake Okada) at Hokkaido University, financed by the Ministry of Education, Culture, Sports, Science and Technology, Japan to S. Tochinai.

\section{References}

AGATA K. (2003). Regeneration and gene regulation in planarians. Curr Opin Genet Dev 13: 492-496.

BAGUNA J,, SALO E AND AULADELL C. (1989). Regeneration and pattern formation in planarians. III. Evidence that neoblasts are totipotent stem cells and the source of blastema cells. Development 107: 77-86.

BAKER M.W, PATERSON S.M AND MACAGNO E.R. (2008). The receptor phosphatase HmLAR2 collaborates with focal adhesion proteins in filopodial tips to control growth cone morphology. Dev Biol 320: 215-225.

BAKER M.W AND MACAGNO E.R. (2000). RNAi of the receptor tyrosine phos phatase $\mathrm{HmLAR} 2$ in a single cell of an intact leech embryo leads to growth-cone 
collapse. Curr Biol 10: 1071-4

BISWAS S.C, DUTT A, BAKER M.W AND MACAGNO E.R. (2002). Association of LAR-like receptor protein tyrosine phosphatases with an enabled homolog in Hirudo medicinalis. Mol Cell Neurosci 21: 657-670.

BELY A.E. AND WRAY G.A. (2001). Evolution of regeneration and fission in annelids: insights from engrailed- and orthodenticle-class gene expression. Development 128: 781-791.

BODE H.R. (1996). The interstitial cell linage of hydra: a stem cell system that arose early in evolution. J Cell Sci 109: 1155-1164.

CABRERA-SERRANO A. AND GARCIA-ARRARAS J.E. (2004). RGD-containing peptide inhibit intestinal regeneration in sea cucumber Holothuria glaberrima. Dev Dyn 231: 171-178.

DONALDSON D.J., MAHAN J.T. AND SMITH GN JR. (1987). Newt epidermal cell migration in vitro and in vivo appears to involve Arg-Gly-Asp-Ser receptors. $J$ Cell Sci 87:525-34

DUPIN F., COULON J., LE PARCO Y., FONTES M. AND THOUVENY Y. (1991) Formation of the extracellular matrix during the epimorphic anterior regeneration of Owenia fusiformis: autoradiographical and in situ hybridization studies. Int J Dev Biol 35: 109-119.

GARDINER D.M., ENDO T. AND BRYANT S.V. (2002). The molecular basis of amphibian limb regeneration: integration the old with the new. Semin Cell Dev Biol 13: 345-352.

JAMIESON B.G.M. (1981). The ultrastructure of the oligochaeta. Academic Press: p. 150-177.

JAZWINSKA A., BADAKOV R. AND KEATING M.T. (2007). Activin-betaA signaling is requires for zebrafish fin regeneration. Curr Biol 17: 1390-1395.

KAWAMOTO S., YOSHIDA-NORO C. AND TOCHINAI S. (2005). Bipolar head regeneration induced by artificial amputation in Enchytraeus japonensis (Annelida, Oligochaeta). J Exp Zoolog 303: 615-627.

KENNERDELL J.R. AND CARTHEW R.W. (1998). Use of dsRNA-mediated genetic interference to demonstrate that frizzled and frizzled 2 act in the wingless pathway. Cell 95: 1017-1026.

LEVESQUE M., GATIEN S., FINNSON K., DESMEULES S., VILLIARD E., PILOTE M., PHILIP A. AND ROY S. (2007). Transforming growth factor: Beta signaling is essential for limb regeneration in axolotls. PLOS ONE 2: e1227.

LOHMANN J.U, ENDL I AND BOSCH T.C. (1999). Silencing of developmental genes in Hydra. Dev Biol 214: 211-214.

MANNINI L., DERI P., GREMIGNI V., ROSSI L., SALVETTI A. AND BATISTONI R. (2008). Two msh/msx-related genes, Djmsh1 and Djmsh2, contribute to the early blastema growth during planarian head regeneration. Int J Dev Biol 52: 943-952.

MARTINEZ V.G, MENGER G.J. 3RD AND ZORAN M.J. (2005). Regeneration and asexual reproduction share common molecular changes: upregulation of a neural glycoepitope during morphallaxis in Lumbriculus. Mech Dev 122: 721 732.

MILJKOVIC-LICINA M., GHILA L., CHERA S. AND GALLIOT B. (2007). Head regeneration in wild-type hydra requires de novo nourogenesis. Development 134: 1191-1201.

MONTAGNOLI A., FIORE F., EYTAN E., CARRANO A.C., DRAETTA G.F., HERSHKO A. AND PAGANO M. (1999). Ubiquitination of p27 is required by Cdk-dependent phosphorylation and trimeric complex formation. Genes Dev 13: 1181-1189.

MORACZEWSKI J., ARCHACKA K., BRZOSKA E., CIEMERYCH M.A., GRABOWSKA I., JANCZYK-ILACH K., STREMINSKA W. AND ZIMOWSKA M. (2008). From Planarians to Mammals - the many faces of regeneration. Int J Dev Biol 52: 219-227.

MYOHARA M. (2004). Differential tissue development during embryogenesis and regeneration in an Annelid. Dev Dyn 231: 349-358.

MYOHARA M., NIVA C.C. AND LEE J.M. (2006). Molecular approach to annelid regeneration: cDNA subtraction cloning reveals various novel genes that are upregulated during the large-scale regeneration of the Oligochaete, Enchytraeus japonensis. Dev Dyn 235: 2051-2070.

MYOHARA M., YOSHIDA-NORO C., KOBARI F. AND TOCHINAI S. (1999). The fragmentation oligochaeta Enchytraeus japonensis: a new material for regeneration study. Dev. Growth Differ 41: 549-555.

NISHIZUKA Y. (1992). Intracellular signaling by hydrolysis of phospholipids and activation of protein kinase C. Science 258: 607-614.

NIVA C.C, LEE J.M. AND MYOHARA M. (2008). Glutamine synthetase gene expression during the regeneration of the annelid Enchytraeus japonensis. Dev Genes Evol 218: 39-46.

O'KANE S. AND FERGUSON M.W. (1997). Transforming growth factor betas and wound healing. Int J Biochem Cell Biol 29: 63-78.

PAGANO M., TAM S.W, THEODORAS A.M., BEER-ROMERO P., DEL SAL G. CHAU V., YEW P.R, DRAETTA G.F. AND ROLFE M. (1995). Role of the ubiquitin-proteasome pathway in regulating abundance of the cyclin-dependent kinase inhibitor p27. Science 269: 682-685.

PAL J.K., MARTINS DE SA C. AND SCHERRER K. (1994). Differential synthesis and cytolocalization of proteasomes in chick embryos during development. Int J Dev Biol 38: 525-534

REDDIEN P.W., BERMANGE A.L., MURFITTK.J., JENNINGS J.R. AND SANCHEZ ALVARADO A. (2005). Identification of genes needed for regeneration, stem cell function, and tissue homeostasis by systematic gene perturbation in planaria. Dev Cell 8: 635-649.

RUOSLAHTIE. AND PIERSCHBACHER M.D. (1986). Arg-Gly-Asp: a versatile cel recognition signal. Cell 44: 517-518

SAMBROOK J. AND DAVID W.R. (2001). "Molecular Cloning: A Laboratory Manual, 3rd Edition. Cold Spring Harbor Laboratory Press: Cold Spring Harbor. NY

SANCHEZ ALVARADO A. (2006). Planarian regeneration; its end is its beginning. Cell 124: 241-245

SANCHEZ ALVARADO A AND TSONIS P.A. (2006). Bridging the regeneration gap: genetic insights from diverse animal models. Nat Rev Genet 7: 873-884.

SHEFI O., SIMONNET C., BAKER M.W., GLASS J.R., MACAGNO E.R. AND GROISMAN A. (2006). Microtargeted gene silencing and expression in live embryos using biolistic delivery with a pneumatic capillary gun. J Neurosci 26 6119-6123.

SUGIO M., TAKEUCHI K., KUTSUNA J., TADOKORO R., TAKAHASHI Y., YOSHIDA-NORO C. AND TOCHINAI S. (2008). Exploration of embryonic origins of germline stem cells and neoblasts in Enchytraeus japonensis. Gene Expr. Patterns. 8: 227-236.

TADOKORO R., SUGIO M., KUTSUNA J., TOCHINAI S. AND TAKAHASHI Y. (2006). Early segregation of germ and somatic lineages during gonadal regeneration in the Annelid Enchytraeus japonensis. Curr Biol 16: 1012-1017.

TAKEO M., YOSHIDA-NORO C. AND TOCHINAI S. (2008). Morphallactic regeneration as revealed by region-specific gene expression in the digestive tract of Enchytraeus japonensis (Oligochaeta, Annelida). Dev Dyn 237: 1284-1294.

TAILLANDIER D., COMBARET L., POUCH M.N., SAMUELS S.E., BECHET D. AND ATTAIX D. (2004). The role of ubiquitin-proteasome-dependent proteolysis in the remodeling of skeletal muscle. Proc Nutr Soc 63: 357-361.

THUMMEL R., BAI S., SARRAS M.P. JR., SONG P., MCDERMOTT J., BREWER J., PERRY M., ZHANG X., HYDE D.R. AND GODWIN A.R. (2006). Inhibition of zebrafish fin regeneration using in vivo electroporation of morpholinos against fgfr1 and msxb. Dev Dyn 235: 336-346.

YANG D., LU H. AND ERICKSON J.W. (2000). Evidence that processed small dsRNAs may mediate sequence-specific mRNA degradation during RNAi in Drosophila embryos. Curr Biol 10: 1191-1200.

YOSHIDA-NORO C., MYOHARA M., KOBARI F. AND TOCHINAI S. (2000). Nervous system dynamics during fragmentation and regeneration in Enchytraeus japonensis (Oligochaeta, Annelida). Dev Genes Evol. 210: 311-319. 


\section{Further Related Reading, published previously in the Int. J. Dev. Biol.}

See Special Issue Pattern Formation edited by Michael K. Richardson and Cheng-Ming Chuong at:

http://www.ijdb.ehu.es/web/contents.php?vol=53\&issue=5-6

Ceratitis capitata transformer-2 gene is required to establish and maintain the autoregulation of Cctra, the master gene for female sex determination

Marco Salvemini, Mark Robertson, Benjamin Aronson, Peter Atkinson, Lino C. Polito and Giuseppe Saccone

Int. J. Dev. Biol. (2009) 53: 109-120

Two $\mathrm{msh} / \mathrm{msx}$-related genes, Djmsh1 and Djmsh2, contribute to the early blastema growth during planarian head regeneration Linda Mannini, Paolo Deri, Vittorio Gremigni, Leonardo Rossi, Alessandra Salvetti and Renata Batistoni Int. J. Dev. Biol. (2008) 52: 943-952

Maternal RNAs encoding transcription factors for germline-specific gene expression in Drosophila embryos

Jun Yatsu, Makoto Hayashi, Masanori Mukai, Kayo Arita, Shuji Shigenobu and Satoru Kobayashi

Int. J. Dev. Biol. (2008) 52: 913-923

Spa-1 regulates the maintenance and differentiation of human embryonic stem cells Young-Jin Lee, Hee-Young Nah, Seok-Ho Hong, Ji-Won Lee, Ilkyung Jeon, Jhang Ho Pak, Joo-Ryung Huh, Sung-Hoon Kim, Hee-Dong Chae, Byung-Moon Kang, Chul Geun Kim and Chung-Hoon Kim

Int. J. Dev. Biol. (2008) 52: 43-53

The role of alpha-amidated neuropeptides in hydroid development-LWamides and metamorphosis in Hydractinia echinata

Günter Plickert, Eva Schetter, Nicole Verhey-Van-Wijk, Jörg Schlossherr, Marlis Steinbüchel and Martin Gajewski

Int. J. Dev. Biol. (2003) 47: 439-450

Functional analysis of the eye genetic network in planarian regeneration D Pineda, J Gonzalez-Linares, M Marsal, E Salo

Int. J. Dev. Biol. (2001) 45: S123-S124

Selective inhibition of gene expression by RNAi in chick embryos in ovo V Hernandez-Hernandez, J Fernandez, A Cardona, R Romero, D Bueno Int. J. Dev. Biol. (2001) 45: S99-S100

Hydrocortisone perturbs the cell proliferation pattern during feather morphogenesis: evidence for disturbance of cephalocaudal orientation

$X$ Desbiens, $N$ Turque and B Vandenbunder

Int. J. Dev. Biol. (1992) 36: 373-380

Analysis of a unique molecule responsible for regeneration and stabilization of differentiated state of tissue cells

Y Imokawa, S Ono, T Takeuchi and G Eguchi

Int. J. Dev. Biol. (1992) 36: 399-405

Formation of the extracellular matrix during the epimorphic anterior regeneration of Owenia fusiformis: autoradiographical and in situ hybridization studies

F Dupin, J Coulon, Y Le Parco, M Fontes and Y Thouveny

Int. J. Dev. Biol. (1991) 35: 109-119

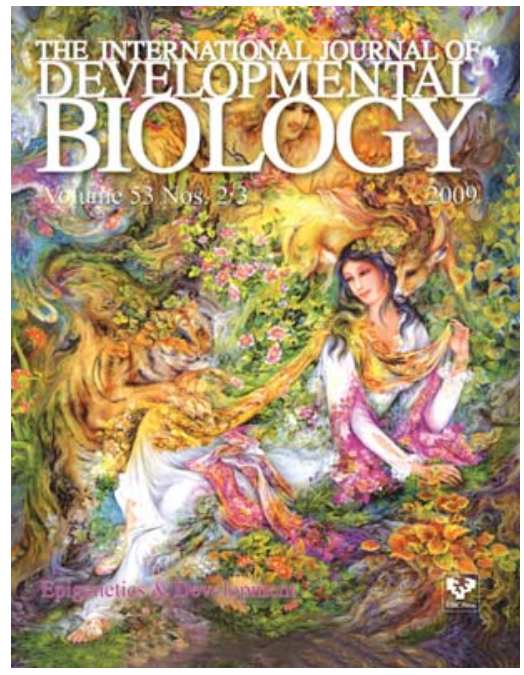

5 yr ISI Impact Factor $(2008)=3.271$

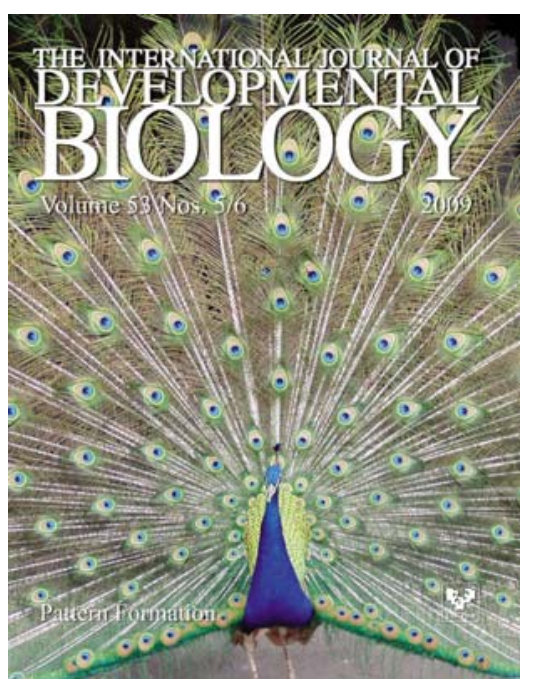

